\title{
The role of NGOs in promoting salience of stakeholders and social issues
}

\author{
Natalia Yakovleva*, Diego Alfonso Vazquez-Brust** and Tuyara N. Gavrilyeva***
}

\begin{abstract}
This paper aims to explore how non-governmental organisations (NGOs) influence environmental governance, public policy and recognition of social issues and social groups. From a conceptual standpoint, the study examines how NGO activism affects salience of stakeholders and salience of social issues in public policy. It is based on longitudinal study of NGO activism in a Russian Arctic region during oil pipeline construction and qualitative analysis of interviews and secondary data collected during 2006 and 2019. The study uses a theoretical lens of environmental governance and salience as applied to stakeholders and social issues, and utilises Salience and Institutional Analysis and Design framework in qualitative data analysis. The study reveals that NGOs activism leads to changes in public policy, elevates salience of indigenous peoples as stakeholders and their concerns within the nexus of business-government-community operating at operational, collectivechoice and constitutional levels of environmental governance. New public policy incrementally addresses social issues at collective-choice level but actually limits the radical change at the constitutional level of environmental governance. As a result, NGO participation in public policy adds external legitimacy to government innovations, while paradoxically reifying the exclusion of indigenous peoples' groups from critical functions of environmental governance such as distribution of benefits from resource use and participation in modification of governance solutions.
\end{abstract}

Keywords: stakeholder salience, salience and institutional analysis and design, indigenous peoples, NGO activism, social impact assessment

* Newcastle University London, Newcastle University Business School, Newcastle University, London, 102 Middlesex Street, London, E1 7EZ, United Kingdom, email: natalia.yakovleva@newcastle.ac.uk.

** Portsmouth Business School, University of Portsmouth, Richmond Building, Portland Street, Portsmouth, PO1 3DE, United Kingdom, email: diego.vazquez-brust@port.ac.uk.

*** North-Eastern Federal University, Engineering and Technical Institute, North-Eastern Federal University, 50 Kulakovsky Street, Yakutsk, 677000, Republic of Sakha (Yakutia), Russian Federation, email: tuyara@list.ru. 


\section{INTRODUCTION}

Non-governmental organisations (NGOs) play an important role in advocate for social and environmental courses and actively pursue activities to influence environmental governance (Crossley, 2003; Bertels et al, 2014; de Bakker et al, 2013 2014). NGOs can shape powerful resistance to business and industry operations by forming coalitions at local, national and transnational scales (Kraemer et al, 2013). There are still gaps in understanding the processes, dynamics, and power struggles around NGOs' contribution to public policy and environmental governance in particular (Kraemer et al, 2013; Mena and Waeger, 2014). Whilst, the interaction between different activist groups with regards to public policy discussions and their ability to advance alternative solutions to environmental governance is not fully explored (Yakovleva \& Vazquez-Brust, 2018).

It is recognised that for an actor to be able to influence decision making, an actor has to possess attributes of stakeholder salience (Mitchell et al., 1998). Academic research suggests that 'salience' of a social actor as a stakeholder and salience of a social issue are related, but separate concepts (Bundy et al, 2013). Here, the theoretical gap under consideration is the ability of NGOs to influence 'salience of social issues' and 'salience of social groups' as separate entities. This paper aims to examine a key research question: How can NGOs influence the 'salience of stakeholders' affected by industrial projects and how can they increase the' salience of social issues' arising from industrial projects?

We explore our research question through a longitudinal case study of NGO activism in the Russian Artic region of Yakutia. Industrial development in the Arctic (e.g. oil, gas, mining, energy and infrastructure projects) spark potent concerns around 'social issues' such as protection of indigenous peoples' rights, potential adverse impacts on local livelihoods, community participation of in decision-making around industrial planning, environmental degradation, climate change impacts, social development and conflicts around access to natural resources between state, industry and local communities (Emerson \& Lahn, 2012; Milov et al, 2006; Fondahl \& Sirina, 2006; UN, 2009). Global, national and local NGOs advocate for greater recognition of indigenous peoples' rights and environmental protection during industrial project planning and implementation in the Artcic. In 2010, this Russian Arctic region has introduced a new law on 
compulsory impact assessment of planned industrial projects on affected indigenous peoples' groups and related evaluation of compensations, e.g. e.g. Ethnological Expert Review (EER) 2010 (Potravnyy et al, 2016; Sleptsov, 2015).

Through 14 years (2006-2019), we follow how NGO activism influenced this new regional 'statebased solution' to environmental governance challenge and investigate whether this regional government solution comprehensively addresses social problems, improves participation of affected parties, wellbeing and traditional livelihood of local and indigenous peoples' communities in the region (Gavrilyeva et al, 2019; Novikova, 2018; Potravnyy et al, 2016). Over 100 semistructured interviews and secondary data were collected during several fieldwork trips conducted during 2006 and 2019. We use interpretive qualitative analysis to explore interactions in the nexus of business-government-community (Dahan et al, 2015; Tashman \& Raelin, 2013) by adopting Salience and Institutional Analysis and Design (SIAD) framework (Yakovleva \& Vazquez-Brust, 2018) combining with the literature on social movement and advocacy networks (Mena \& Waeger, 2014; Kraemer et al, 2013).

We found that even in constrained institutional environments where civil society organisations face powerful government and industry interests such as in Russia, NGO activism is capable of positively influencing public policy. The study reveals that it is the reformative indigenous peoples (IP) NGOs which possess a network structure and political ties with regional government that take a lead in transforming the regional advocacy network through aligning with identity and strategic interests of regional government. This process elevates a particular 'social issue' in the public debate - protection of IP rights, but retains another 'social issue' - environmental protection at the same level. Although EER (the achieved 'state-based solution' to environmental governance challenge) addresses NGO activism and increases the salience of IP stakeholders at the collectivechoice level of governance, has limitations of invoking its radical change at the constitutional level of governance. As a result, participation NGO activism in the public debate adds external legitimacy to regional government solution, while reifying the exclusion of IP from critical governance functions such as distribution of benefits from natural resource use and participation on decision-making on industrial planning, thus constraining the salience of indigenous peoples as stakeholders. 
The paper is organised as follows. Section two reviews the literature on the role of social movements and NGO activism in environmental governance; section three outlines research methods; section four presents the findings of the longitudinal study; section five discusses the implications of study and section six presents major conclusions.

\section{NON-GOVERNMENTAL ORGANISATIONS AND ENVIRONMENTAL GOVERNANCE}

\subsection{Non-governmental organisations and advocacy for social change}

The core of social movement research focuses on understanding the dynamics of social interactions. It studies how outsider activist groups often challenge established social and regulatory institutions in an attempt to bring about social and political change (Mena \& Waeger, 2014). In their work, activist groups often have limited resources at their disposal, and they must prioritize targets and tactics, the choice that is largely informed by ideology (Bertels et al, 2014). Mena \& Waeger (2014) distinguish between radical and reformative ideologies. Radical activist groups emphasize problems within corporate activities of firms, whilst reformative activist groups focus on achieving workable solution with firms, even if these activities do not fully address corporate responsibility (CR) issues comprehensively. Radical activist groups spend much of their time and resources deinstitutionalizing what are considered current CR best practices, which they consider unsatisfactory or intermediary solutions. They concentrate on targeting and criticizing more advanced and proactive firms and typically prefer disruptive, non-institutionalized tactics to gain high media and public attention (Mena \& Waeger, 2014). Reformative groups, on the other hand, value best practices as intermediary solutions and necessary steps before advanced measures. Moderate ideologies of reformative groups acknowledge that firms are a part of potential future solutions, as well as being part of the problem itself (Mena \& Waeger, 2014). Reformative activist groups tend to focus their time and resources on working with proactive firms, as well as criticizing laggards (Mena \& Waeger, 2014).

Transnational advocacy networks (TAN) bring local, national and international social movements and international NGOs together. It is assumed that social movements, especially when amplified by TAN, can influence salience of particular social issues. TANs are often conceptualized using a 
well-known boomerang model, which describes that transnational advocacy networks aid domestic activist with weaker powers, lacking know-how and material resources to influence policy and practice change. This view considers that local activism is at the 'periphery' of a stronger global advocacy movement. Thus, local organizations seek support from TANs when facing high levels of repression domestically and lacking political resource to influence policy change (Kraemer et al, 2013).

Further, Kraemer et al (2013) introduced a concept of national advocacy network (NAN) that consists of national activists, NGOs, community organizations, research organizations and independent media groups that are engaged in national-level advocacy on behalf of numerous local struggles in remote parts of the country. NANs, with their focus on domestic goals, operate alongside internationally oriented actors, this may result in collaboration but also in conflict and disruption. Kraemer et al (2013) assert that NANs operate according to the same principles as TANs, empowering local grassroots activists through the provision of technical and strategic knowhow and leveraging local information into broader campaigns to influence national power holders. NANs and the grassroots groups they support often do have various pathways of influencing the state and corporations. Local resistance strategies (such as blocking access roads to prevent construction of a mine) can be surprisingly effective in delaying progress of projects and nationallevel lobbying under democratic circumstances might result in political influence-taking on corporations.

NGOs experience limitations in inducing change to existing environmental governance, especially with regards to industrial development, where many powerful actors and global forces are at play. Teegen et al (2004) state that NGOs often lack legitimacy domestically, as they are challenged about their motives, actions and contribution to collective good. To increase their legitimacy and bargaining power, NAN activists refer to TANs that can disseminate information globally and gather broader support for the social course (Kraemer et al, 2013). In turn, TANs and NANs interact with local or Regional Advocacy Networks (RAN) that are closer to communities and experiences of social issues. 
The dynamic interactions between different actors from business, government and civil society and advocacy networks influence environmental governamce during industrial development with potent outcomes for public policy and practice on consideration of environmental and social implications of economic activities. We conceptualize them as nested within a nexus of businessgovernment-community (Dahan et al, 2015), that is also relevant to three-sector bargaining model suggested by Teegen et al (2004). Despite its importance, there is little knowledge of how interactions within the nexus influence solutions to environmental governance challenges. The next section will explore how the nexus interactions shaping environmental or natural resource governance can be studied using a multi-level, multi-actor and multi-functional framework of Salience and Institutional Analysis and Design (SIAD) (Paavola, 2007; Yakovleva \& VazquezBrust, 2018).

\subsection{Salience and institutional analysis and design (SIAD) framework for the analysis of environmental governance}

Ostrom and colleagues (Ostrom, 2009, 2010) developed the institutional analysis and design framework to systematize the analysis of solutions to resource degradation and depletion associated with the use of common-pool resources such as water resources and forests. Their framework offers helpful ways to examine interactions between actors and institutions across three interlinked levels: operational, collective-choice and constitutional, which are regulated by formal and informal rules. Ostrom describes the operational level as a level where rules and decisions about resource access and management impact the physical world. The collective-choice level is a level where rules of resource use are designed and policy making involves several actors are conducted. The constitutional level is where higher order rules are made that impact both collective-choice and operational levels, these are rules on policy making and design of solutions to resource governance challenges (Ostrom, 2009).

Environmental sustainability can be sought through development of solutions that require establishment of rules that define exclusion, entitlement, monitoring and decision-making on access and use of common-pool resources (Clement, 2010; Ostrom, 2009, 2010). Importantly, Ostrom and colleagues argue for self-regulation and cooperation between actors is a successful 
solution to preservation and continued sustainable use of common-pool resources (Ostrom, 2009). Paavola $(2007,2016)$ proposes three types of governance solutions to the resolution of resource conflicts: 'state-based solution', 'community-based solution' and 'co-management solution' that perform several resource-management functions within the environmental governance system.

Yakovleva \& Vazquez-Brust (2018) propose the integration of stakeholder theory with the institutional analysis and design framework (Ostrom, 2010; Paavola, 2016). The Salience and Institutional Analysis and Design framework (SIAD) proposes that interactions between businessgovernment-community (Dahan et al, 2015; Tashman \& Raelin, 2013) and consideration of individual actors and their concerns in development of 'environmental governance solutions' are affected by the actors mutual assessment of 'stakeholder salience' using attributes of power, legitimacy and urgency (Mitchell et al, 1997) across levels of governance system (operational, collective-choice and constitutional). Stakeholder salience assessments made by actors within each level can determine which actors can access decision-making on resource use and foresee the outcomes for various actors, especially when private companies are involved in resource use that rival for use of resources with other actors. Stakeholder salience can change over time influenced by interactions of business-government-community nexus, where parties impact each other's assessment on the importance of social groups (with attributes of legitimacy, power and urgency) and where legitimacy of social groups is lacking it can be elevated in the nexus through a process of "legitimization through engagement" (Yakovleva \& Vazquez-Brust, 2018). The SIAD framework suggests that changing salience of stakeholders allows fringe stakeholders (with low salience) to gain core stakeholder (with high salience) status to be considered in the design of environmental governance solutions by governments and firms.

In this paper, we conceptualize and analytical extension of SIAD to integrate 'issue salience' in the framework. While 'stakeholder salience' is recognised as an important element in manager's decision-making (Mitchell et al., 1997), Bundy et al (2013, p. 353) suggest that manager's responsiveness to stakeholder concerns is subject to "strategic cognition view of issue salience, which we define as the degree to which a stakeholder issue resonates with and is prioritized by management... managers do not respond to stakeholder and environmental characteristics per se. Instead, they respond to specific issues and concerns advocated by stakeholders." Bundy et al. 
(2013) and Roloff (2008) distinguish between 'salience of stakeholders' as social groups from the 'salience of social issues' which stakeholders champion for, these are seen as separate, but related concepts. Although Bundy et al. (2013) propose that manager's responsiveness a 'social issue' can be interpreted by degree of significance of a 'social issue 'and its relevance to organisational identity and strategic frame. However, it is not fully explored how 'issue salience' is changed over time and what role do stakeholders advocating for 'social issues' play in elevating their significance. As NGOs challenge government and firm responses to 'social issues', it is important to study the role of NGO in influencing 'salience interpretation' processes to advance the understanding the dynamics between 'issue salience' and 'stakeholder salience'. The SIAD framework can allow to study the interplay between 'issue salience' and 'stakeholder salience' by tracking the interactions of government-business-community nexus across operational, collectivechoice and constitutional levels, and evaluating the outcomes of resulting 'governance solutions' for 'social issues' and 'stakeholders'.

\subsection{Management of environmental and social issues during industrial projects in the}

\section{Russian Arctic}

The Russian state pursues a policy of expansion of extractive and other industrial projects in the Arctic, affecting the livelihood of indigenous peoples, whilst lacking a comprehensive policy for consultation, social impact assessment and compensation (Fondahl and Sirina, 2006; O'Faircheallaigh and Ali 2008). Russian state recognises and protects the rights of select minority indigenous peoples with a total population of 258,000 people comprising of 40 nations who reside in the Russian North, Siberia and Far East that lead traditional activities of hunting, fishing, plant gathering and reindeer herding (collectively called the indigenous peoples of the North) (Fondahl et al, 2001; Fondahl \& Sirina, 2006; Gavrilyeva et al, 2019; Potravnyy et al, 2017; Soloviev et al, 2014). Despite an extensive body of legislation, living spaces of indigenous peoples fall into focus of national economic policies for commercial exploitation of mineral and natural resources by oil, gas, mining, energy and infrastructure companies (Gulakov \& Vanclay, 2018; Semenova, 2007; Stammler \& Peskov, 2006; Stammler \& Wilson, 2006; Xanthaki, 2004). IP of the North do not possess land ownership rights (outside of municipal settlements), but registered IP groups (groups formed around kinship ties organise themselves in 'IP communes' to conduct traditional activities) 
can register user rights for land, that enable traditional resource use practices, but these are under continuous threat of withdrawal into industrial use (Potravnyy et al, 2016, 2017).

Under the federal legislation, removal of land from IP groups or other resource users into industrial use results in compensation to the affected users for the loss of income. All significant industrial projects undergo an environmental impact assessment (EIA) that prescribes public consultation with local communities, but does not offer specific consideration of IP rights (Kovalev \& Koeppel, 2003; Novikova, 2018; Yakovleva, 2012, 2014). Accompanying federal methodology on evaluation of land use activities, loss of income and compensation to affected land users does not take stock of impacts on traditional activities of IP. Evidence demonstrates that existing federal legislation on EIA and compensation lead low compensation amounts, community discontent and limited participation of IP groups in industrial planning process (Yakovleva, 2012, 2014).

Further solutions to the protection of IP rights can be found in "Ethnological Expert Review" (EER), a form of social impact assessment designed for indigenous peoples that is not yet functional at the national level in Russia (Murashko, 2006; Novikova, 2017). Instead, separate Russian regions (e.g. Yakutia and Sakhalin) introduce regional legislation on EER applicable on the territory of individual regions only (Gavrilyeva et al, 2019; Potravnyy et al, 2017; Sleptsov, 2015). In Yakutia, EER1 was introduced in 2010 under the pressure from NGOs, notably regional civil coalition "Our Home - Yakutia" that emerged during the construction of Eastern Siberia- Pacific Ocean (ESPO) oil pipeline (Sleptsov, 2015; Potravnyy et al, 2017; Yakovleva, 2014). Neither federal EIA nor regional EER are considered to be comprehensive mechanisms for protection of the natural environment and IP rights during the industrial planning (Gavrilyeva et al, 2018; Novikova, 2018; Potravnyy et al, 2017). However, it is not understood how NGOs influenced the regional government to prioritize one 'social issue' such as IP interests over other 'social issue' such as environmental protection during industrial planning, and how the 'salience' of IP groups changes as a result. 


\section{RESEARCH METHODS}

We conducted a longitudinal case study (Yin, 2003) of industrial development in Yakutia in 20062019, one of the Russian regions - officially referred to as the Republic of Sakha (Yakutia). Yakutia is a home for several IP nations of the North - Chukchis, Dolgans, Evens, Enenki and Yukagirs with a total population of 40,000 people who access and use forests and natural resources under formal and informal rules that evolved in the region (Leonov \& Shevareva, 2017).

EER introduced in Yakutia in 2010 is conceived as a new regional 'state-based solution' to environmental governance with regards to industrial planning and associated environmental and social implications. EER is used in addition to federal EIA that is seen as a national 'state-based solution' in this study. EER is a mandatory state-sanctioned assessment of new industrial projects for their impacts on and damage to 'traditional natural resource use' activities of registered IP groups (those who are formally registered as IP communes and have secured land use entitlements for 'traditional natural resource use') (see Table 1). EER evaluates the amounts of compensation due to registered IP groups and potentially can be applied in 52 territories of 'traditional natural resource use' that are registered in Yakutia as of 2016 (see Gavrilyeva et al, 2018; Potravnyy et al, 2017).

Data collection: We conducted over 100 semi-structured interviews and secondary data collected during fieldwork and on internet (see Table 1). Interviews included IP and local communities; regional NGOs; government departments; municipal authorities; and companies. Interviewees were selected using a snowballing technique (Gifford et al, 2010). Prominent NGOs and regional government departments were contacted, leading to further development of local community and IP contacts. The access to IP communities was negotiated via local municipal authorities, IP community leaders and facilitated by regional university. All respondents were offered confidentiality, anonymity and voluntary participation. Interview questions explored topics of impacts, consultation, compensation and benefits of industrial projects. When interviewees did not permit audio recording, interviews notes were taken instead. Participatory and non-participatory observation of public hearing meetings and conferences was conducted, where recording of public talks, debates and presentations from regional government, industry and civil society, including IP speakers were made. 
Secondary data includes summaries of EER completed in 2012-2016 and published on website of Ministry for Development of the Institutes of Civil Society of Yakutia (Minobchestvo, 2019), and information published on government, business and NGO websites, regional and national news sites. Triangulation of secondary and primary sources was conducted to verify facts and accounts (Yin, 2003). Field notes containing observations and iterative analysis of data during the study were made to build chronologies of the events and record working theories (Yakovleva \& VazquezBrust, 2018).

\section{Table 1. Data collection during 2006-2019 in Yakutia}

\begin{tabular}{|l|c|c|}
\hline Data sources & Fieldtrips 2006-2009 & Fieldtrip 2018-2019 \\
\hline Primary data & & \\
\hline $\begin{array}{l}\text { Semi-structured interviews, including recordings of public } \\
\text { speeches and debates }\end{array}$ & 52 & 42 (out of 66) \\
\hline$-\quad$ Indigenous peoples & 21 & 6 \\
\hline$-\quad$ Civil society organisations & 17 & 11 \\
\hline$-\quad$ Regional and municipal state authorities & 6 & 2 \\
\hline$-\quad$ Industrial organisations & - & 4 \\
\hline$-\quad$ Academics & 195 & \\
\hline Secondary data & & \\
\hline $\begin{array}{l}\text { Documents produced by regional government, regional } \\
\text { advocacy network and media news }\end{array}$ & & 17 \\
\hline Documents on EER and compensation to IP in 2012-2018 & & \\
\hline
\end{tabular}

Data analysis The study aims to analyse whether the salience of IP communities has changed, looking at elements of power, urgency and legitimacy across these governance functions and what was the role of regional advocacy network in influencing this change. The first stage of data analysis involved thick description narratives (Lincoln \& Guba, 1985), which are accounts of advocacy network formation and its work on IP and environmental issues, that are conducted with an aim to construct sequence of events and describe the interactions between actors and characterise various outcomes. The second stage included thematic analysis of interviews that was applied to examine the change in governance solutions, its functions and corresponding rules-in-use across operational, collective-choice and constitutional levels following the SIAD framework. Themes responded to the SIAD with the data first codes into operational, collective choice and 
constitutional level, then by functions of natural resource use governance in each level: 1) authorisation of resource users; 2) regulation of authorized use and distribution of benefits and costs; 3) monitoring and enforcement of resource users and conflict resolution; 4) design and modification of governance solutions; and across institutional levels: 1) operational; 2) collectivechoice, 3) constitutional; and finally coding for stakeholder salience ( power, legitimacy, urgency and issue type (IP, environment). Nodes were created in NVIVO and relations dynamically mapped and later interpreted.

\section{FINDINGS: NGO ACTIVISM DURING INDUSTRIAL PROJECTS IN THE RUSSIAN ARCTIC}

\subsection{Role of NGOs in environmental governance in Yakutia}

Regional NGO activism in Yakutia and their contribution to environmental governance has evolved through distinct phases in the studied period (see Table 2).

Phase 1 Emergence of NGO activism. Although environmental NGOs existed in Yakutia since the late 1980s, environmental activism started to be very vocal in 2006-2007 in the context of public discussions around ESPO oil pipeline and other industrial projects, mainly led by a group of environmental NGOs and activists. During this phase, activist groups started to examine industrial project plans, appeal to government and industry organisations for greater environmental scrutiny in an attempt to challenge industrial narratives. They started to gather support from local and IP communities, schools and initiated advocacy and public awareness work with a release of public statements and open letters to government officials and company managers, demanding changes to planning decisions, emphasising environmental risks, lack of comprehensive consideration of social, economic, environmental implications and suggesting innovative approaches to impact assessment, benefit sharing and control over industrial projects. As such, these interest-based NGOs called for radical change to procedures, logics and approaches to industrial planning and consideration of regional community interests.

"Now we have two main tasks: oil pipeline, its construction and operation. The inevitability of accidents, in fragile natural environments with very low recovery rates, is a great risk of destroying the river and polluting the ocean met with complete indifference on the other side (authorities, Transneft and controlling structures). And the worst thing is a plan to build large hydropower plants on the rivers of Yakutia. We intend to contest the legitimacy of 
these plans in the very near future. At the moment, it seems to be the same as the turn of Siberian rivers, a crazy and dangerous project". (Interview with Environmental NGO, August 2006).

Phase 2 Consolidation of NGO activism. In the second period (2008-2009), environmental, IP NGOs and other civil society activists started to gain greater cohesion on key issues of environmental protection, IP rights and economic benefits trying to contest corporate and government solutions with a confrontational tactics to gain greater public support by releasing independent EIA on oil pipeline project, continuing to write open letters to state officials, filing law suits to contest the legality of public hearings and forming a Civil Coalition "Our HomeYakutia" comprising of several environmental and identity-based NGOs (see Table 2). This coalition launched a public campaign "Save Lena!” highlighting environmental risks of pipeline by attracting school pupils, using art and public demonstrations, spreading information through internet and collecting signatures for public petitions. The coalition managed to achieve considerable public support and awareness issues of sustainability governance using public demonstrations in Yakutsk, which was met with opposition from regional government and business.

"We, participants of the civil action "Save Lena!"... express deep concern for the fate of our great Siberian river Lena... This concern is caused by the construction of ESPO oil pipeline, which is undertaken without high-quality exploratory works and conducted with numerous breaches of environmental protection legislation and technical requirements and no recall to the recommendations from leading Yakutian scientists, independent experts and opinions of the population... We express mistrust in project developer of ESPO oil pipeline, Transneft Company. We consider that saving money in this case is inapplicable, immoral and criminal." (extract from the Open Letter to President Medvedev from the committee of Save Lena campaign, July 2008).

Phase 3 Decline of NGO activism. In the third phase (2009-2011), it has become apparent that the regional government is supportive of impact assessment and compensation to IP groups, securing land entitlements, whilst environmental concerns advocated by environmental groups were less supported. In fact, the most prominent environmental NGO in RAN, Centre for Environmental Education "Eyge" declined considerably in its influence on government-business-community interactions due to change of leadership and lack of regional government support (Interview with academic, August 2018). The introduction of EER in 2010 allowed to shift the discussions from 
solution seeking to implementation and operationalisation of solution, reducing the opposition to industrial projects.

Phase 4 Transformation of NGO activism. The fourth phase began in 2011 onwards. IP NGOs such as the Association of indigenous peoples of the North of Yakutia, Association of Evenki of Yakutia and Association of Even of Yakutia thrived and given support from regional government. As IP NGOs are seen to be reformative, open to constructive dialogue with government and industry. For instance, in 2017, the Association of indigenous peoples of the North of Yakutia received a grant from the President Putin and organised series of high-profile conferences and multi-stakeholder roundtables attracting speakers from industry, government, academia and representatives from neighbouring Northern and Far Eastern regions of Russia (Interviews and Observations in August 2018 and March 2019). Other IP NGOs organise regular conferences that discuss wider IP issues of health, education, culture, language and industry relations, which are supported and funded by regional and local authorities, including support of festivals and culture days such as Day of Reindeer Herder and Days of Indigenous Peoples (Interviews and Observations in March 2019). IP NGOs actively share knowledge, experiences and practices developed in Yakutia through workshops and seminars with other Russian regions where EER is yet to be developed with an aim to empower national IP communities (Meeting with civil society organisations, August 2018).

"We have conducted many seminars with IP groups in an attempt to increase legal literacy of local communities. We cannot say we have captured everyone, but those who were interested to attend have gained certain level of knowledge... They know their rights, often questions occur about their actual use...We have taught companies to make contacts with municipal authorities and IP groups. More or less we can observe this. Though majority of agreements have a framing character and a lot of general words. However, the recognition and curtsies demonstrate that companies understand the way to go". (Interview with IP NGO, August 2018).

Evolution of NGO activism and bargaining processes within the nexus of business-governmentcommunity led to two outcomes: 1) IP interests that are promoted by identity-based NGOs (e.g., IP NGOs) overtook in the discussions on wider environmental and social issues, that were championed by radical interest-based NGOs (e.g., Environmental NGOs); 2) Assessment and compensation to registered IP groups arose as regional state-based solution displacing other radical suggestions. Four major reasons for the rise of IP NGOs against Environmental NGOs at the collective-choice level can be cited: 1) extended network structure of IP NGOs, who have local 
identity-based and formal members in cities, towns and villages with growing links to national and international IP NGOs and IP communities in the Russian North, Arctic and Circumpolar North; 2) strong political links of IP NGOs with local, regional government authorities, members of parliament and academia reinforced by notions of national identity and concern for IP community as a whole and their relation to natural resources; 3 ) reformative and moderate nature of IP NGOs made them open to dialogue with industry and government without demands on radical shifts in governance at collective-choice level; 4) focus on specific social, economic and environmental issues bounded by place, community and identity and thus manageable at a regional level; and 4) alignment of IP NGOs with regional government based on the narrative of concern for control of regional economic, land and natural resources, promotion of local economic development, and strengthening regional, national and cultural identities.

On the contrary, Environmental NGOs failed to build stable and extended networks, despite links with schools and education institutions, lacking decisive political ties, resources and support from the National Advocacy Network (NAN). As NAN achieved earlier success in averting potential environmental hazards from lake Baikal, it could no longer support RAN on related environmental issues. Environmental, planning and local community issues to consult, protest, share benefits promoted by interest-based NGOs were seen as more radical, trans-regional and outside of regional government remit, thus limiting opportunities for alignment with government interests and objectives. Claims and proposals of interest-based NGOs received lower legitimacy from regional government and industry and were perceived as lacking in professional expertise, ignoring economic development priorities, and unachievable.

Overall, it is evident that the most powerful decision-makers (federal government and headquarters of industrial companies) are located at the core, i.e. at national level, whilst regional government and regional NGOs are at the periphery of a bargaining processes (see Figure 1). Though NAN belongs to the core, their influence of government and industry is limited due to lack of institutional structures. Though regional NGOs could face same barriers when targeting regional government and business, regional NGOs managed to achieve considerable policy change through influence on perceptive regional government. This policy change has some potential to influence national government decisions and thus national industry practice (Interview with academic, August 2018) 
(see Figure 1). Regional government has increased its own power in bargaining with new industrial projects by overseeing state EER, facilitating compensations and strengthening political influence. IP interests are is highly relevant to organisational identity of the regional government in the region that has considerable population of IP, pursuing improvement of economic welfare and control for economic and natural resources.

Figure 1. Influence of NGOs on bargaining with government and business

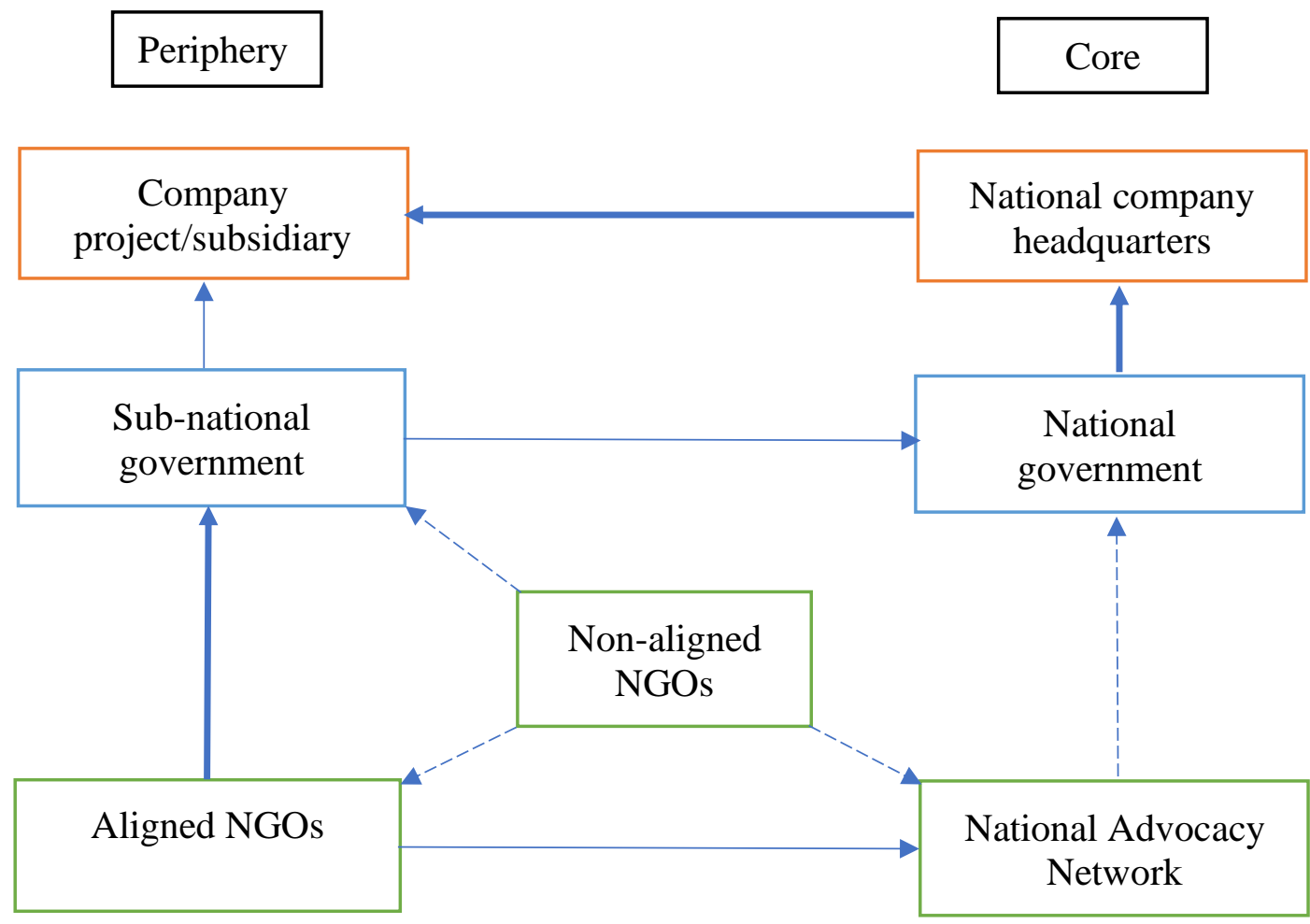


Table 2. Evolution of environmental governance in Yakutia, 2004-2019

\begin{tabular}{|c|c|c|c|}
\hline Year & Government (federal, regional, municipal) & Business (national, regional) & $\begin{array}{l}\text { Community (transnational, national, } \\
\text { regional, local) }\end{array}$ \\
\hline 2004 & $\begin{array}{l}\text { Government of Russia approves oil pipeline } \\
\text { "Eastern Siberia Pacific Ocean" (ESPO) in } \\
\text { December. }\end{array}$ & $\begin{array}{l}\text { ESPO led public consultations on oil pipeline } \\
\text { construction near Lake Baikal. }\end{array}$ & $\begin{array}{l}\text { National environmental NGOs supported by } \\
\text { international environmental NGOs (Greenpeace } \\
\text { and WWF) protest against planning of oil } \\
\text { pipeline near Lake Baikal (RIA Novosti 2006; } \\
\text { Kommersant, 2006). }\end{array}$ \\
\hline 2006 & $\begin{array}{l}\text { Government of Russia proposes to shift the } \\
\text { pipeline northwards from Lake Baikal in April } \\
\text { (Ria Novosti, 2006). Decision is made to } \\
\text { expand ESPO into the territory of Yakutia. }\end{array}$ & $\begin{array}{l}\text { Public hearing meetings on environmental } \\
\text { impacts of ESPO extension in Yakutia are held } \\
\text { in cities of Yakutsk, Aldan and Neryungri as } \\
\text { part of EIA in April. }\end{array}$ & $\begin{array}{l}\text { Emergence of regional public activism } \\
\text { questioning environmental, social and } \\
\text { environmental impacts and planning decisions } \\
\text { on ESPO. }\end{array}$ \\
\hline 2007 & & $\begin{array}{l}\text { Construction of ESPO oil pipeline in Yakutia } \\
\text { commences in January. }\end{array}$ & $\begin{array}{l}\text { Regional NGOs are writing letters, contesting } \\
\text { planning decisions in court and conducted } \\
\text { alternative EIA. }\end{array}$ \\
\hline 2008 & & $\begin{array}{l}\text { Compensations are awarded to registered IP } \\
\text { groups in Aldan district of Yakutia for removal } \\
\text { of land from traditional natural resource use into } \\
\text { industrial use. }\end{array}$ & $\begin{array}{l}\text { Formation of civil coalition "Our Home - } \\
\text { Yakutia" comprising of organisations: Network } \\
\text { of Public Monitoring; Centre for Environmental } \\
\text { Education "Eyge"; Public Environmental } \\
\text { Centre; Sakha Public Centre; and Association of } \\
\text { Evenki (SakhaNews, 2008). Formation of civil } \\
\text { action "Save Lena!" under the civil coalition } \\
\text { "Our Home - Yakutia" that organised public } \\
\text { demonstration in Yakutsk and collected 20,000 } \\
\text { signatures in protest against crossing over the } \\
\text { river Lena by ESPO (Save Lena, 2008). }\end{array}$ \\
\hline 2009 & $\begin{array}{l}\text { Regional government provides financial support } \\
\text { to IP communities to register plots of land as } \\
\text { "territories of traditional natural resource use" }\end{array}$ & $\begin{array}{l}\text { Completion of Stage } 1 \text { of ESPO between } \\
\text { Taishet and Skovorodino, including the route } \\
\text { within Yakutia. }\end{array}$ & \\
\hline 2010 & $\begin{array}{l}\text { Adoption of regional law on "Ethnological } \\
\text { expert review" by the government of Yakutia in } \\
\text { April. }\end{array}$ & & \\
\hline 2011 & $\begin{array}{l}\text { Detailed regional regulations on EER comes } \\
\text { into force in Yakutia, enabling the } \\
\text { operationalization of EER. }\end{array}$ & & \\
\hline 2012 & $\begin{array}{l}\text { First state EER is conducted in Yakutia. } \\
\text { Government of Russia approved development of } \\
\text { a gas pipeline "Power of Russia". }\end{array}$ & & \\
\hline
\end{tabular}




\begin{tabular}{|l|l|l|l|}
\hline $\mathbf{2 0 1 5}$ & $\begin{array}{l}\text { State EER on gas pipeline "Power of Siberia" is } \\
\text { conducted in Yakutia in November. } \\
\text { Local municipal authority in Olenek district of } \\
\text { Yakutia filed court case contesting the award of } \\
\text { license to Diamonds of Anabar, which was } \\
\text { dismissed at arbitration court (CSIPN, 2015). }\end{array}$ & & \\
\hline $\mathbf{2 0 1 7}$ & & & $\begin{array}{l}\text { Project "Dialogue of indigenous peoples of the } \\
\text { North in Republic of Sakha (Yakutia) with } \\
\text { industrial companies in 2017-18" is awarded to } \\
\text { the Association of Indigenous Peoples of } \\
\text { Yakutia and funded by a grant from the } \\
\text { President of Russia (Fund of President Grants, } \\
\text { 2019). }\end{array}$ \\
\hline $\mathbf{2 0 1 8}$ & $\begin{array}{l}\text { Regional MP discusses legislative initiative to } \\
\text { extend land rights of IP (YSIA, 2018). }\end{array}$ & $\begin{array}{l}\text { Construction of gas pipeline is completed from } \\
\text { Chayandinski gas deposit in Yakutia until the } \\
\text { border with China in June. }\end{array}$ & $\begin{array}{l}\text { Multi-stakeholder meetings between } \\
\text { government, industry, academia and NGOs on } \\
\text { IP and industry organized by IP NGO. }\end{array}$ \\
\hline $\mathbf{2 0 1 9}$ & $\begin{array}{l}\text { Regional government introduces a new Ministry } \\
\text { for Development of Arctic and Affairs of } \\
\text { Nations of the North in the Republic of Sakha } \\
\text { (Yakutia) (GRSY, 2019). }\end{array}$ & $\begin{array}{l}\text { Gas production in Chayandinksi gas deposit in } \\
\text { Yakutia is planned to commence. }\end{array}$ & \\
\hline
\end{tabular}




\subsection{Outcomes of national and regional state solutions to environmental governance}

Involvement of IP in industrial planning processes in Russia is regulated at three hierarchical levels - federal, regional and municipal. When comparing the two state-based solutions on natural resource governance (EIA as national solution and EER as regional solution), the evidence demonstrates that EER brings distinct changes at collective-choice and operational level rules and outcomes for IP but fails to challenge EIA at the constitutional level (i.e., the national geographical scale and federal regulatory level) (see Table 3).

Authorisation of resource users EER does not offer additional solution to authorisation of resource users, which remains to be ruled by federal government. Federal rules also govern registration of land for use by registered IP groups. Regional government has helped financing land registration costs of registered IP groups (Interview with academic, March 2019). The EER applies only to registered IP groups with registered land rights to participate in impact assessment and compensations, excluding unregistered IP groups and local residents around industrial projects that access and use natural resource using informal rules (Interview with IP NGO, March 2019). Another solution to protection of IP lands is the formation of "specially protected territories of municipal significance", that allows municipal authorities to engage in planning process and negotiations on alternative land use introduced by the state and industry.

Regulation of authorized use and distribution of benefits and costs The EER formalises rules on assessment of impacts on traditional activities of IP after all new projects are approved by the state; refinement of compensation methodology; allows one-off or annual payments to IP during lifespan of industrial projects. Compensations per member of IP groups have increased from 3,000 USD in 2012 to up to 6,070 USD in 2016 (Interview with leader of IP group, August 2018), though current compensations payments under EER do not exceed 1\% of project values (Gavriliyeva et al, 2019).

"At the time, we did not have the ethnological expert review. Following the agreements, only few IP groups received compensations. Until now, everything is shrouded in darkness, some say that only four groups received compensations, some say eight. But the total number of groups affected by pipeline's passing is eighteen." (Interview with IP NGO, August 2018). 
Table 3. Comparison of EIA and EER as solutions to the governance of natural resources

\begin{tabular}{|c|c|c|}
\hline $\begin{array}{l}\text { Governance } \\
\text { functions }\end{array}$ & Environmental impact assessment (national solution) & Ethnological expert review (additional regional solution) \\
\hline $\begin{array}{l}\text { 1. Authorization } \\
\text { of resource users }\end{array}$ & $\begin{array}{l}\text { CONSTITUTIONAL LEVEL } \\
\text { - Federal rules define authorised users, IP registered as NGO or SME are } \\
\text { granted land rights. Federal rules exclude unregistered indigenous } \\
\text { peoples' groups from accessing land. } \\
\text { COLLECTIVE CHOICE LEVEL } \\
\text { - Regional rules govern registration of IP groups and allocation of land } \\
\text { OPERATIONAL LEVEL } \\
\text { - Informal rules give unregistered IP customary rights to access land use. } \\
\text { Informal rules exclude IP users without local linkages. }\end{array}$ & $\begin{array}{l}\text { COLLECTIVE CHOICE LEVEL } \\
\text { - } \quad \text { Regional rules govern registration of IP groups and allocation of land } \\
\text { - } \\
\text { Regional rules include registered IP in EER process. Registered and } \\
\text { unregistered give input through community surveys. } \\
\text { - } \quad \begin{array}{l}\text { Regional rules include registered IP in compensation process but still } \\
\text { exclude unregistered IP. Registered IP give input to compensation } \\
\text { process. }\end{array} \\
\text { OPERATIONAL LEVEL } \\
\text { - Informal rules give unregistered IP customary rights to access land use. } \\
\text { Informal rules exclude IP users without local linkages. }\end{array}$ \\
\hline $\begin{array}{l}\text { 2. Regulation of } \\
\text { authorized use } \\
\text { and distribution of } \\
\text { benefits and costs }\end{array}$ & $\begin{array}{l}\text { CONSTITUTIONAL LEVEL } \\
\text { - } \quad \text { Federal rules regulate authorised use to registered IP with permits. } \\
\text { - } \quad \text { Federal rules on EIA offer consultation to generic local communities } \\
\text { around industrial projects, without specific consultation offered to IP. } \\
\text { - } \quad \text { Federal rules prescribe compensation to registered IP groups using } \\
\text { federally accepted methodology for removal of land from traditional } \\
\text { natural resource use into industrial use. } \\
\text { - Federal rules include registered IP in compensations and exclude } \\
\text { unregistered IP compensations. Registered IP give input to } \\
\text { compensation process. } \\
\text { - Federal rules regulate removal of registered IP land from traditional } \\
\text { natural resource use into industrial use. } \\
\text { COLLECTIVE CHOICE LEVEL } \\
\text { - Federal rules prescribe compensation to registered IP groups using } \\
\text { federally accepted methodology for removal of land from traditional } \\
\text { natural resource use into industrial use. } \\
\text { Federal rules exclude unregistered IP from EIA and Compensation. } \\
\text { Registered IP give input to compensation process but are excluded from } \\
\text { EIA process. } \\
\text { Companies cooperate with registered IP groups through philanthropy } \\
\text { and purchase of traditional products such as meat, fish and other goods. } \\
\text { OPERATIONAL LEVEL } \\
\text { Authorized resource users (such as companies and registered IP) } \\
\text { cooperate with unauthorized resource users (unregistered IP) to permit }\end{array}$ & $\begin{array}{l}\text { COLLECTIVE CHOICE LEVEL } \\
\text { - } \quad \text { Regional rules prescribe assessment of impact of industrial activities on } \\
\text { registered IP groups and instructs industrial developers to compensate } \\
\text { for damage. Registered IP excluded from EIA process. } \\
\text { - Regional rules include registered IP in EER process. Registered and } \\
\text { unregistered give input through community surveys. Regional rules } \\
\text { include registered IP in compensation process but still exclude } \\
\text { unregistered IP. Registered IP give input to compensation process. } \\
\text { - Industrial companies implement corporate social responsibility } \\
\text { initiatives for benefit of registered and unregistered IP and local } \\
\text { community } \\
\text { OPERATIONAL LEVEL } \\
\text { - Authorized resource users (such as companies and registered IP) } \\
\text { cooperate with unauthorized resource users (unregistered IP) to permit } \\
\text { access to resources and informally distribute the benefits from resource } \\
\text { use. }\end{array}$ \\
\hline
\end{tabular}




\begin{tabular}{|c|c|c|}
\hline & $\begin{array}{l}\text { access to resources and informally distribute the benefits from resource } \\
\text { use. }\end{array}$ & \\
\hline $\begin{array}{l}\text { 4. Design and } \\
\text { modification of } \\
\text { governance } \\
\text { solution }\end{array}$ & $\begin{array}{l}\text { CONSTITUTIONAL LEVEL } \\
\text { - Federal rules resolve conflict administratively through state departments } \\
\text { or legally through the court system. Registered IP do not input in design } \\
\text { of compensation methodology or EIA. } \\
\text { COLLECTIVE CHOICE LEVEL } \\
\text { - Focus on federal government decision-making powers. } \\
\text { Resource users have limited forums to engage in dialogue with } \\
\text { authorised resource users. } \\
\text { EIA does not effective ways to local communities, including IP, to } \\
\text { modify project specifications that affects final solutions. } \\
\text { OPERATIONAL LEVEL } \\
\text { Limited ability of local communities to influence the modification of } \\
\text { governance solution via public consultation meetings. }\end{array}$ & $\begin{array}{l}\text { COLLECTIVE CHOICE LEVEL } \\
\text { - Through EER, the position of regional government in design of } \\
\text { solutions is promoted. } \\
\text { - Companies, state authorities, civil society organisations are involved in } \\
\text { design of solutions at the regional scale, which does not effectively } \\
\text { capture registered and unregistered IP. } \\
\text { OPERATIONAL LEVEL } \\
\text { - Greater degree of negotiation between companies and registered and } \\
\text { unregistered IP for CSR and community development. }\end{array}$ \\
\hline
\end{tabular}


In addition, IP NGOs through advocacy work, and regional government through direct financial and institutional support have helped IP groups to assume their rights and register land plots as "territories of traditional natural resource use" in 2010 (Interviews, March 2019). The regional government by overseeing the processes of impact assessment and compensation has increased its powers thus grew in salience assessment by corporate managers. It is evident that companies are now considering the concerns of IP groups and local communities.

"Within the agreement on socio-economic development, we build, repair and modernise units of social infrastructure, purchase specialist equipment for municipal authorities, support traditional way of life. Besides the agreement, the company offers various support to municipalities from solving current problems to targeted support of population. Support is extended practically to all aspects of livelihood with consideration of the specifics of Arctic region, large distances, extreme climatic conditions. We as good neighbours try not to ignore those issues and needs of villagers." (extractive company during round table, August 2018).

Monitoring and enforcement of resource users and conflict resolution State authorities fail to enforce the rules of exclusion of unauthorized users due to limited capacity, but access to natural resources is governed by informal community rules that are support by pragmatic approach and community logic of resource sharing at the operational level. This cooperation exists due to lack of resources in rural areas and principles of reciprocity. However, in extreme cases IP communities enter in conflict and direct confrontation with unauthorized land users, such as poachers (Interview with municipal authority, August 2018). Cooperation is generally preferred to IP communities who seek support from regional government and business to help with enforcement of user rights. When industrial companies fail to comply, municipal organisations have attempt to defend IP communities through the court of law (Meeting with municipal and regional authorities, August 2018). Regional government has increased their capacity to monitor impact assessment by opening a new Ministry for Arctic Affairs in 2019 that contributes to increase of their salience (see Table $3)$.

“Gold companies work IP groups... they have agreements... There are conflicts...It's good that we have quite a good experience in the region in this regard... Municipal administrations are getting involved, so we have some influence mechanism... But the fact that the region and those large companies, they are in fact transnational companies, such as Surgutneftegas, ESPO, Gazprom and their subsidiaries, follow international regulation, so they have to consider us. But there is another conflict, the Republic as a region of Russia enters into agreements with the companies. They provide inflows into regional budget, which are evenly distributed between regional districts. It appears that those localities, 
where extraction is taking place are left with nothing." (Discussions with member of IP NGO, March 2019).

Design and modification of governance solutions EER gained considerable support amongst regional NGOs (Interview with civil society organisation, August 2018) and is praised for progressive nature. However, being a state-based solution at regional level it does not offer mechanisms for IP to be involved in modification and design alternative solutions as these are controlled primarily by regional government and national government. Although IP NGOs promote EER amongst IP communities in the Russian North and discuss opportunities to enhance the compensation methodology, the IP communities are excluded from making paramount decision of what projects come to their territories. In this function, EER does not offer any additional powers to IP groups, thus maintaining the existing salience status of IP in the governance system.

"Now we now pose a question about increasing the participation of indigenous peoples of the North at all stages of ethnological expert review process, starting from development of documents and finishing with a decision of expert commission and its monitoring. Actually, at present, it seems though the law is for indigenous peoples, but without them. Whilst international practice suggests - Nothing About Us Without Us". (Interview with IP NGO, August 2018).

\section{DISCUSSION: CONTRIBUTION OF NGOS TO SALIENCE ASSESSMENT}

NGOs were clearly instrumental in elevating stakeholder status of indigenous peoples at the operational and collective-choice levels. However, the salience status of indigenous peoples of the North at the constitutional level will not improve unless the federal government introduces further legislative changes. EER is a new state-based solution that clearly improves the salience of three groups of actors with regards to industrial companies at the collective-choice level: registered IP groups with registered land rights; reformative IP NGOs; and regional government. State regulation in Russia with municipal, regional and federal regulation roughly corresponds to institutional levels in SIAD - operational, collective-choice and constitutional.

As EER emerged at the collective-choice level, it impacts on salience of registered IP groups at collective-choice and operational levels. However, the Power of IP groups has not improved at the constitutional level as EER is unable to advance IP further to higher stages of participation in the planning process as it does not offer free prior informed consent or veto rights. It does not offer IP 
groups the control for natural resources or allow them to contribute to design and modification of governance solutions. Other governance solutions which entail control of land (e.g. registration of municipal land as "specially protected territories" and proposed legislative initiative on extending land rights to IP) can extend the Power of IP groups in the interactions with industrial companies. The Urgency of IP claims has slightly improved with EER at the collective-choice and operational levels as new industrial projects cannot ignore addressing IP concerns due to legal compliance and litigation can be further strategy for IP groups to defend their rights. As EER a regional solution it has critical limitations. Only the changes at the constitutional level, i.e. a comprehensive national legislation can considerably improve the urgency of IP claims across the nation. A major factor in strengthening the Legitimacy of IP groups is the support from regional government and NGOs. Here, the process of "legitimization" in the nexus of business-government-community is applicable (Yakovleva \& Vazquez-Brust, 2018), if government offers support to specific actors lacking legitimacy, then business acknowledges their legitimacy as stakeholders. EER certainly adds to legal legitimacy of IP groups and their claims, formalising the moral legitimacy of IP groups grounded in human rights. However, the EER does not fully address concerns of wider IP communities, local non-IP communities and does not deal with other claims of IP groups (e.g. loss of cultural heritage due to industrial development).

Importantly, IP NGOs and regional government have increased their own salience as stakeholders in the governance system with regards to business and national government, instead of increasing the salience of IP communities per se. We find that this alignment is grounded on principles proposed by Bundy et al (2013): identity (that could be described national, ethnic, northern, placebased identity) and strategic interests (control over resources and strengthening bargaining power within the nested national and sub-national system of interactions of business-governmentcommunity nexus). The alignment (Bertels et al, 2014) is further strengthened by the reformative approach adopted by IP NGOs (Mena \& Waeger, 2014), and supported by network structure and coalition-building that allows IP NGOs to learn, facilitate, advocate and lobby on wide range of IP issues. Not only the alignment between NGOs and government is effective in developing incremental governance solutions, but coalition building can strengthen bargaining positions in their respective work. The incremental advancement in governance solutions may gain a positive 
long-term trajectory of addressing social issues - in the case study, the discussions have moved from impact assessment to potential legislative changes to IP land rights (YSIA, 2018).

It appears that reformative IP NGOs have replaced the radical faction of RAN, i.e. Environmental NGO from tables of negotiations with the regional government and have settled for incremental, achievable solutions within the institutional environment and gained greater salience against Environmental NGOs in the assessment of state and company managers (see Figure 2).

\section{Figure 2. Nexus interactions across institutional levels}

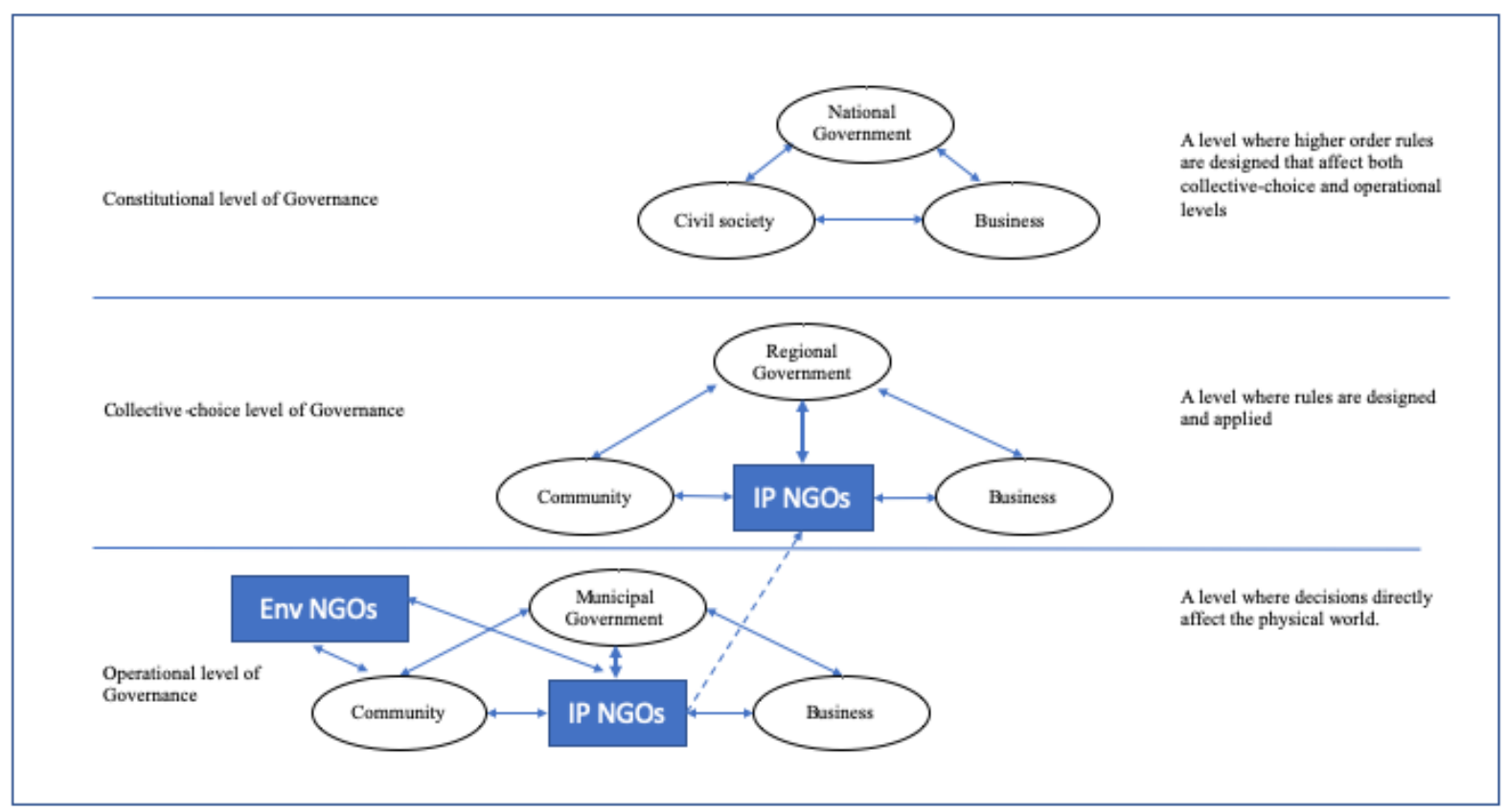

IP NGOs, though building greater cohesion, network structure and political ties, are working on developing a lasting narrative of socio-economic development in the Arctic and their continuous aligned work on identity can expand the appeal to other groups, beyond IP communities (e.g. other nations of the region, other regions in the Russian North, Siberia and Far East and local non-IP communities). IP NGOs are now skilled in collaborating and communicating with other members of RAN, NAN, TAN, communities, business and government across various institutional levels and geographical scales not only for their own benefit but making an input to strengthen the work on NAN. Within the network of IP NGOs in Yakutia, the Association of the Indigenous Peoples of 
the North of the Republic of Sakha (Yakutia) is a focal member of network, that is an umbrella organisation for other regional IP NGOs and has most resources, political ties and links with IP NGOs outside of the regional, national and transnational IP NGOs. Its social position has been of coordinator and facilitator (Bertels, et al, 2014).

We find that RAN has clearly contributed to amplification IP interests and rights as a salient stakeholder issue by adopting a variety of tactics: protest, consultation, litigation, facilitation and collaboration that fall into themes developed by Bertels et al (2014): creating, disrupting, amplifying and aligning. We suggest that assessment of salience of social issues (environmental protection and IP rights) by NAN and TAN is not comprehensive without RAN input. We propose that if NGOs to be effective in influencing governance solutions they should continue working both on increasing salience of individual groups as stakeholders and salience of social issues as stakeholder claims. The first allows salient stakeholders to participate directly in the design of governance solutions on matters that affect them, and second allows consideration of salient social issues in multi-stakeholder discussions on the design and implementation of governance solutions that affect complex sustainability challenges.

\section{CONCLUSION}

We contribute to the social movement theory by identifying the key role of RANs in increasing previously understudied issue salience. We also observe that through displaying collaboration, reformative RAN and radical RAN compete for resources to increase the salience of social issues they respectively advocate for. Our study suggests that increased salience of a social issue does not necessarily lead to significant elevation in salience of a corresponding social group. Despite the increased salience of indigenous peoples' protection as an issue, the participation of IP as stakeholders in natural resource governance has not significantly improved. IP are not part of major governance functions such as authorisation of resource use, regulation of users, monitoring of natural resource use and design of governance solutions. Instead, another actor, in this case the regional government, by capturing indigenous peoples' protection as a social issue gains greater position within the system of environmental governance vis-à-vis other actors in the system, e.g. federal government, in order to advance their interests and powers in federal-regional political 
relations. Our results highlight the importance of looking at issue and stakeholder salience across governance levels. Salience of a stakeholder at operational and collective-choice levels might be deceiving. Within environmental governance, unless a governance solution (whether it is statebased, community-based or collaborative) improves the salience of social groups at a constitutional level, the nexus members of business-government-community tend to ignore stakeholder claims and interests in decision-making, resulting in adverse impacts on the stakeholders. Targeting key stakeholders within environmental governance system, especially those who influence rule making at the constitutional level, becomes a paramount prerogative for NGO activism to advance the effectiveness of environmental governance solutions.

\section{REFERENCES}

Bertles, D., Hoffman, A.J., \& DeJordy, R. 2014. The varied work of challenger movements: Identifying challenger roles in the US environmental movement. Organization Studies, 35(8): 1171-1210.

Bryman, A., \& Bell, E. 2015. Business Research Methods (4th ed.). Oxford: Oxford University Press.

Bundy, J., Shropshire, C., \& Buchholtz, A.K. 2013. Strategic cognition and issue salience: Toward an explanation of firm responsiveness to stakeholder concerns. Academy of Management Review, 38 (3): 352-376.

Clement, F. 2010. Analysing decentralised natural resource governance: Proposition for politicised institutional analysis and development framework. Policy Science, 43: 129-156.

Centre for Support of Indigenous Peoples of the North (CSIPN). 2015. Arbitration Court Sided with the Manufacturers. 16 October 2015. Available at: http://www.csipn.ru/korennyenarody-i-promyshlennye-kompanii/2155-arbitrazhnyj-sud-vstal-na-storonupromyshlennikov (accessed 7 December 2019).

Crossley, N. 2003. Even newer social movements? Anti-corporate protests, capitalist crises and the remoralization of society. Organization, 10(2): 287-305.

Dahan, N. M., Doh, J. P., \& Raelin, J. D. 2015. Pivoting the role of government in business and society interface: A stakeholder perspective. Journal of Business Ethics, 131: 665-680.

de Bakker, F.G.A., den Hond, F., King, N., \& Weber, K. 2013. Social movements, civil society and corporations: Taking stock and looking ahead, Organization Studies, 34(5-6): 573-593.

den Hond, F. and de Bakker, F. G. A. 2007. Ideologically motivated activism: How activist groups influence corporate social change activities. Academy of Management Review, 32(3): 901924.

Emerson, C. \& Lahn, G. 2012. Arctic Opening: Opportunity and Risk in the High North. London: Chatham http://www.chathamhouse.org/publications/papers/view/182839 (accessed 1 September 2014). 
Erdiaw-Kwasie, M. O., Alam, K., \& Shahiduzzaman, M. 2017. Towards understanding stakeholder salience transition and relational approach to 'better' corporate social responsibility. Journal of Business Ethics, 144: 85-101.

Fondahl, G. \& Sirina, A. 2006. Rights and risks: Evenki concerns regarding the proposed Eastern Siberia - Pacific Ocean Pipeline. Sibirica, 5(2): 115-38.

Fondahl, G., Lazebnik, O., Poelzer, G. \& Robbek, V. 2001. Native land claims, Russian style. The Canadian Geographer, 45(4): 545-61.

Fund of President Grants (2019). Dialogue of Indigenous Peoples of the North in Republic of Sakha (Yakutia) with Industrial Companies. Available at: https://xn-80afcdbalict6afooklqi5o.xn--p1ai/public/application/item?id=78a1a0dc-322c-4275-8c45f261fccea38a (accessed 7 December 2019).

Gavrilyeva, T.N., Mostakhova, T.S., Boyakova, S.I., Yakovleva, N.P., \& Bochoeva, R.I. 2018. Damage compensations towards indigenous minority peoples of Yakutia for land industrialization. Region: Economy and Sociology, 3(99): 234-251 [publication in Russian].

Gavrilyeva, T.N., Yakovleva, N.P., Boyakova, S.I., \& Bochoeva, R.I. 2019. Compensation for impact of industrial projects in Russia to indigenous peoples of the North. In N. Sellheim, Y.V. Zaika \& I. Kelman (Eds.), Arctic Triumph: Northern Innovation and Persistence: 83-103, Switzerland: Springer.

Gibson, G., \& O'Faircheallaigh, C. 2010. The Community IBA Toolkit: Negotiation and Implementation of Impact and Benefit Agreements. Toronto: Walter and Duncan Gordon Foundation. Available at: http://www.ibacommunitytoolkit.ca/pdf/IBA_toolkit_March_2010_low_resolution.pdf (accessed 25/06/2014).

Gifford, B., Kestler, A., \& Anand, S. 2010. Building local legitimacy into corporate social responsibility: Gold mining firms in developing nations. Journal of World Business, 45(3): 304-311.

Gray, D. 2017. Doing Research in the Real World. (4th ed.). London: Sage Publications.

GRSY (Government of the Republic of Sakha (Yakutia)). 2011. Decree of the Government of the RS(Y) of 06.09.2011 No. 428 (edited on 16.02.2017) on Procedure for Organisation and Implementation of Ethnological Expert Review in the Areas of Traditional Settlement and Traditional Economic Activity of Indigenous Minority Nations. Published in Yakutsk Vedomosti, 2011, No. 60 [publication in Russian].

GRSY (Government of the Republic of Sakha (Yakutia)). 2019. Ministry for Development of Arctic and Affairs of Nations of the North of the Republic of Sakha (Yakutia). Available at: https://arktika.sakha.gov.ru/ (accessed 8 December 2019).

Gulakov, I. \& Vanclay, F. 2018. Social impact assessment in the Russian Federation: does it meet the key values of democracy and civil society? Impact Assessment and Project Appraisal, $36: 6,494-505$.

Il Tumen. 2010. 820-Z No 537-IV On Ethnological Expert Review in Places of Traditional Settlement and Traditional Economic Activity of Indigenous Minority Peoples of the North in the Republic of Sakha (Yakutia). Available at: http://docs.cntd.ru/document/895252453 (accessed 13 January 2020).

Il Tumen. 2018. In the Development of Federal Law on Ethnological Expert Review the Experience of the Republic of Sakha (Yakutia) Should be Considered. State Assembly (Il Tumen) of the Republic of Sakha (Yakutia), Yakutsk, Russia [publication in Russian]. 
Available at: http://iltumen.ru/content/v-razrabotke-federalnogo-zakonoproekta-obetnologicheskoi-ekspertize-dolzhen-uchityvatsya-op (accessed 14 January 2019).

Kommersant. 2006. Pipeline of clean water: Diversion of ESPO will keep Baikal, but not the costs for construction. Kommersant Newspaper, No. 75 of 27 April 2019, p. 3 [in Russian]. Available at: https://www.kommersant.ru/doc/670106 (accessed 7 December 2019).

Kovalev, N. \& Koeppel, J. 2003. Introduction to the environmental impact assessment system and public participation in the Russian Federation. Journal of Environmental Assessment Policy and Management, 5(3): 321-38.

Kraemer, R., Whiteman, G., \& Banerjee, B. 2013. Conflict and astroturfing in Niyamgiri: The importance of national advocacy networks in anti-corporate social movements. Organization Studies, 34(5-6): 823-852.

Leonov, S. N., \& Shevareva, Y. S. 2017. Problems and prospects of development of traditional economic activities of indigenous people of Russian Far Eastern North. Regional Studies, 4(2): 26-45 [publication in Russian].

Lincoln, Y. S., \& Guba, E. G. 1985. Naturalistic Inquiry. Beverly Hills, California: Sage Publications.

Mena, S., \& Weagner, D. 2014. Activism for corporate responsibility: Conceptualizing private regulation opportunity structures. Journal of Management Studies, 51(7): 1091-1117.

Milov, V., Coburn, LL. \& Danchenko, I. 2006. Russia's energy policy, 1992-2005. Eurasian Geography and Economics, 47(3): 285-313.

Minobchestvo. 2019. Ministry for Development of the Institutes of Civil Society of Yakutia. Available at : https://minobchestvo.sakha.gov.ru (accessed 6 December 2019).

Mitchell, R. K., Agle, B. R., \& Wood, D. J. 1997. Toward a theory of stakeholder identification and salience: Defining the principle of who and what really counts. Academy of Management Review, 22(4): 853-886.

Moser, E., \& Skripchenko, A. 2018. Russian NGOs and Their Struggle for Legitimacy in the Face of the 'Foreign Agents' Law: Surviving in Small Ecologies, Europe-Asia Studies, DOI: 10.1080/09668136.2018.1444145.

Murashko, O.A. 2006. What is the Etnologicheskaya Ekspertiza in Russia? Sibirica, 5(2): 77-94.

Novikova, N. I. 2017. Anthropological expert review in Russian Federation: Legal grounds and prospects for indigenous people. The Artic. XXI century. Humanitarian Sciences. 3(13): 4-20 [publication in Russian]. Available at: https://cyberleninka.ru/article/v/etnologicheskaya-ekspertiza-v-rossiyskoy-federatsiipravovye-osnovaniya-i-perspektivy-dlya-korennyh-narodov (accessed 14 January 2019).

O'Faircheallaigh, C., \& Ali, S. 2008. Understanding Corporate-Aboriginal Agreements on Mineral Development. In C. O'Faircheallaigh \& Saleem Ali (Eds.). Earth Matters: Indigenous Peoples, the Extractive Industries and Corporate Social Responsibility: 67-82, Sheffield, UK: Greenleaf Publishing.

O'Faircheallaigh, C. 2013. Extractive industries and indigenous peoples: a changing dynamic? Journal of Rural Studies, 30: 20-30.

Ostrom, E. 2009. Beyond Markets and States: Polycentric Governance of Complex Economic Systems Prize Lecture, December 8, 2009. Workshop in Political Theory and Policy Analysis, Indiana University, Bloomington, IN 47408, and Center for the Study of Institutional Diversity, Arizona State University, Tempe, AZ, USA. Available from: https://www.nobelprize.org/uploads/2018/06/ostrom_lecture.pdf (accessed 13 January 2019). 
Ostrom, E. 2010. Beyond markets and states: Polycentric governance of complex economic systems. American Economic Review, 100: 641-672.

Paavola, J. 2007. Institutions and environmental governance: A reconceptualization. Ecological Economics, 63: 93-102.

Paavola, J. 2016. Multi-level environmental governance: Exploring the economic explanations. Environmental Policy and Governance, 26: 143-154.

Platt, G. M., \& Williams, R. H. 2002. Ideological language and social movement mobilization: A sociolinguistic analysis of segregationists' ideologies. Sociological Theory, 20: 328 -359.

Potravnyy I. M., Gassiy V. V., \& Afanasyev S. M. 2017. Territories of traditional nature: development limits or economic growth factors? The Arctic: Ecology and Economy, 2(26): 4-16 [publication in Russian]. Available at: http://en.ibrae.ac.ru/docs/2(26)_2017_Arctic/004_016.pdf (accessed 14 January 2019).

Potravnyy, I.M., Gassiy, V.V., Chernogradnskiy, V.N., \& Postnikov, A.V. 2016. Corporation social responsibility of resource users in territories of traditional natural resource use as a basis of partnership between state, business and indigenous small-numebred peoples of the North. The Arctic: Ecology and Economy, 2(22): 56-63 [publication in Russian]. Available from:

http://en.ibrae.ac.ru/docs/2(22)2016_\%D0\%90\%D1\%80\%D0\%BA\%D1\%82\%D0\%B8\% D0\%BA\%D0\%B0/056_063_ARCTICA_2_2016.pdf (accessed 14 January 2019).

RIA Novosti. 2006. Route of pipeline Eastern Siberia-Pacific Ocean is amended. 27 April 2006. RIA Novosti. Available at: https://ria.ru/20060427/46971764.html (accessed 7 December 2019).

Roloff, J. 2008. Learning from multi-stakeholder networks: Issue-focussed stakeholder management. Journal of Business Ethics, 82: 233-250.

Rowley, T. J., \& Moldoveanu, M. 2003. When will stakeholder groups act? An interest- and identity-based model of stakeholder group mobilization. Academy of Management Review, 28: $204-219$.

SakhaNews. 2008. "Our Home - Yakutia": trench method of crossing ESPO is danfgering due to possible earthquakes. SakhaNews, 28 May 2008 [publication in Russian]. Available from: http://www.1sn.ru/23483.html (accessed 7 December 2019).

Save Lena. 2008. Welcome to the website of civil action "Save Lena!" Available from: http://savelena.ykt.ru/index.php?option=com_frontpage\&Itemid=1 (accessed 7 December 2019).

Semenova, T. 2007. Political mobilisation of northern indigenous peoples in Russia. Polar Record, 43 (224): 23-32.

Shapiro, D., Hobdari, B., \& Hoon Oh, C. 2018. Natural resource, multinational enterprises and sustainable development. Journal of World Business, 53(1): 1-14.

Sleptsov, A.N. 2015. The state ethnologic examination in the Republic of Sakha (Yakutia). The Arctic XXI century. Humanitarian sciences, 1 (4): 15-24 [publication in Russian].

Soloviev, M., Ledkov, G., Grover, R., Yakovleva, N., \& Kiryushkina, E. 2014. Northern indigenous peoples' interests and the responsibility of oil and gas corporations. British Academy of Management Conference, Belfast, September 2014.

Stammler, F., \& Peskov, V. 2008. Building a 'culture of dialogue' among stakeholders in NorthWest Russian oil extraction. Europe-Asia Studies, 60(5): 831-49.

Stammler, F., \& Wilson, E. 2006. Dialogue for development: an exploration of relations between oil and gas companies, communities and the state. Sibirica, 5(2): 1-42. 
Tashman, P., \& Raelin, J. 2013. Who and what really matters to the firm: Moving stakeholder salience beyond managerial perceptions. Business Ethics Quarterly, 23(14): 591-616.

Teegen, H., Doh, J. P., Vachani, S. 2004. The importance of nongovernmental organizations (NGOs) in global governance and value creation: An international business research agenda. Journal of International Business Studies, 35(6): 463-483.

UN (United Nations). 2009. State of the World Indigenous People. New York: United Nations: Available at: http://www.un.org/esa/socdev/unpfii/documents/SOWIP_web.pdf (accessed 1 September 2014).

Xanthaki, A. 2004. Indigenous rights in the Russian Federation: the case of numerically small peoples of the Russian North, Siberia and Far East. Human Rights Quarterly, 26(1): 74 105.

Yakovleva, N. 2012. Oil pipeline construction in Eastern Siberia: Implications for indigenous people. Geoforum, 42 (6): 708-719.

Yakovleva, N. 2014. Land, oil and indigenous people in the Russian North: A case of oil pipeline and Evenki in Aldan, In E. Gilberthorpe \& G. Hilson (Eds.). Natural Resource Extraction and Indigenous Livelihoods: Development Challenges in an Era of Globalization: 147178, Aldershot: Ashgate Publishing.

Yakovleva, N., \& Grover, R. 2015. Crossing the Land of Indigenous People in the Arctic: Comparison of Russian and North American Experiences of Economic Growth and Human Rights in Energy and Infrastructure Projects. In R. Pincus \& S. H. Ali (Eds.). Diplomacy on Ice: Energy and the Environment in the Arctic and Antarctic: 198-212, New Haven, Connecticut: Yale University Press.

Yakovleva, N., \& Vazquez-Brust, D. 2018. Mining multinational enterprises and artisanal smallscale miners: from confrontation to cooperation. Journal of World Business, 53(1): 52-62.

Yin, R. K. 2003. Case Study Research: Design and Methods. Thousand Oaks, California: Sage Publications.

YSIA. 2018. Legal initiative of Il Tumen is supported by parliamentarians in the Far Eastern Federal District. YSIA, published 19 October 2018 [publication in Russian]. Available at: http://ysia.ru/zakonodatelnaya-initsiativa-il-tumena-podderzhana-parlamentariyami-dfo/ (accessed 14 January 2019). 